E-JURNAL EKONOMI DAN BISNIS UNIVERSITAS UDAYANA
Available online at http s://ojs.unud.ac.id/index.php/EEB/index
Vol. 10 No. 12, December 2021, pages: 1087-1096
e-ISSN: 2337-3067

\title{
MENELISIK PERSEPSI PERILAKU MILENIAL PENGGUNA INSTAGRAM DI ERA NEW NORMAL
}

\section{Ni Putu Novia Periantini ${ }^{1}$ Gede Sri Darma $^{2}$}

\begin{tabular}{l}
\hline \multicolumn{1}{c}{ Article history: } \\
\hline Submitted: 21 Mei 2021 \\
Revised: 25 Juni2021 \\
Accepted:13 Juli2021 \\
\\
\hline
\end{tabular}

Keywords:

Marketing 4.0;

Instagram;

Consumer Behavior;

New Customer Path 5A;

\section{Kata Kunci:}

Marketing 4.0;

Instagram;

Perilaku Konsumen;

New CustomerPath 5A;

\section{Koresponding:}

Undiknas Graduate School,

Bali, Indonesia

Email:

noviaperiantini09@gmail.com

Abstract

This study aims to determine the perception of millennial behavior of Instagram users in thenew normal era related to the implementation of customer path 5A. Consumer behavior has changed as a result of the new normal era. The application of customer path $5 A$ can be seen from the millennial behavior of Instagram users starting from the A ware, Appeal, Ask, Act, and Advocate stages. The brand provider company must be a mentor throughout the customer stages from the Aware or awareness stage to the Advocate or endorsement stage. Business actors re ally hope that there will be an Act and Advocate process for products offered to consumers during this new normalera. This study uses a qualitative app ro ach to dig deeper into the millennial behavior of Instagram users throug $h$ customer path 5A. Data was collected through in-depth interviews with 10 millennial female informants with an age range of 18-24 years who are followers of the Instagram account @wimy_store.This study indicates that not all informants go through every stage of the 5 A customer path starting from the Aware, Appeal, Ask, Act and Advocate stages. 2 Informants only went through the Aware, Appeal, and Ask stages, Act or purchase actions were not carried out due to considerations of the Covid-19 pandemic so that they paid more attention to needs, Advocate wasnot carried out because there had never been an Act before.

\begin{tabular}{|c|}
\hline Abstrak \\
\hline 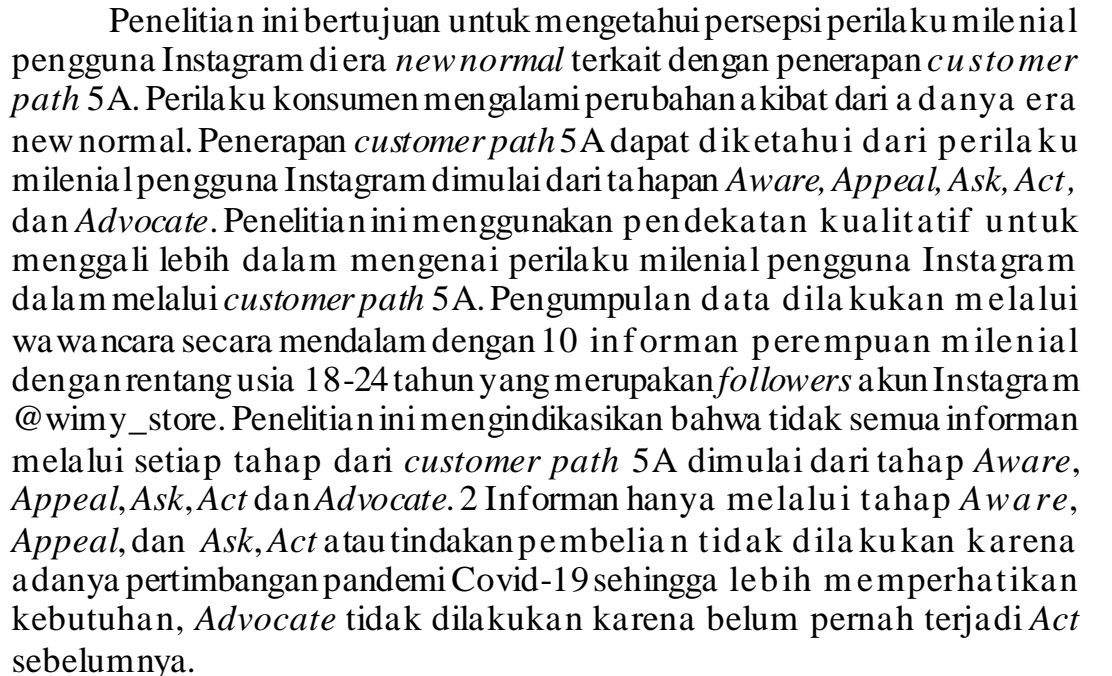 \\
\hline
\end{tabular}

Undiknas Gra duate School, Ba li, Indonesia ${ }^{2}$

Email: sridarma@ undiknas.ac.id ${ }^{2}$ 


\section{PENDAHULUAN}

Fenomena pandemi Covid-19 yang menciptakan suatu era tatanan baru atau era kenormalan baru yang dapat disebut juga dengan era new normal yang menandakan bahwa telah dibukanya kembali aktivitas-aktivitas masyarakat namun dengan tetap mematuhi protokol kesehatan yang tujuannya tidak lain adalah untuk memutus rantai penyebaran dari virus Covid-19 (Barokah et al., 2020). Pemerintah menerbitkan kebijakan yang dimuat dalam Nomor 21 Tahun 2020 mengenai PSBB (Pembatasan Sosial Berskala Besar) yang kemudian dinyatakan berakhir dengan hadirnya era new normal (Sudiyar Dalimunthe, 2020).

Perilaku konsumen saat melakukan pembelian mengalami perubahan, konsumen lebih memperhatikan kebutuhannya yang sangat diperlukan, dengan lebih melihat nilai dari suatu produk. Maka, sebagai pelaku UKM harus dapat beradaptasi untuk menyiasati perubahan ini. Menurut The American Marketing Association mendefinisikan perilaku konsumen sebagai interaksi dinamis antara afeksi dan kognisi, perilaku dan lingkungannya dimana manusia melakukan kegiatan pertukaran dalam hidup mereka (Kanten,\& Darma, 2017). Proses pertukaran yang juga melibatkan transfer dari suatu hal yang berwujud ataupun tidak berwujud, nyata atau simbolik antara dua pelaku sosial bahkan lebih (Kotler, P. \& Keller, 2021).

Para industri usaha akan melakukan segala inovasi agar dapat bertahan di era new normal (Sepri et al., 2020). Inovasi yang dilakukan semakin tidak terlepas dari peran internet, melalui pemilihan dan pemanfaatan dari tekonologi komunikasi yang tepat maka akan dapat meningkatkan kinerja penjualan dari perusahaan (Pratama \& Darma, 2014). Internet pada era digital Marketing 4.0 memiliki dampak yang sangat besar bagi para pelaku usaha, sehingga dengan adanya Marketing 4.0 menjadi sarana yang tepat disaat pandemi dan harus cepat ditangkap sinyalnya agar semakin membuka kesempatan dan juga peluang usaha yang semakin luas dan berkembang (Lugra Agusta Pranawa \& Abiyasa, 2019). Pemanfaatan Marketing 4.0 dengan menggunakan pendekatan pemasaran yang mengombinasikan interaksi online dan offline yang terjadi antara penjual dan konsumen dengan tujuan utamanya untuk memenangkan advokasi konsumen (Kotler et al., 2017).

Menurut Pranata \& Darma (2018), dalam Marketing 4.0 menyarankan adanya perubahan cara dalam memberikan informasi kepada konsumen yaitu menjadi advokasi brand. Perpaduan atau kombinasi antara interaksi online dan offline diperlukan agar saling melengkapi, walaupun di tengah kemajuan teknologi dengan pemasaran online lebih mudah dalam menyasar pelanggan secara luas. Namun, interaksi secara online saja tidak cukup, sehingga harus diimbangi dengan offline agar dapat menyentuh konsumen, sehingga mendapatkan pelayanan memuaskan dari produk atau jasa yang ditawarkan (Kotler et al., 2017).

Jalur atau tahapan dari perilaku pelanggan terhadap sebuah merek dulunya bersifat individual karena hanya terjadi pengulangan dalam pembelian, kemudian di era Marketing 4.0 telah berubah menjadi New Customer Path 5A yang terdiri dari Aware, Appeal, Ask, Act, dan Advocate yang bersifat sosial karena adanya rekomendasi atau penganjuran dari orang lain. Keputusan pembelian yang dulunya bersifat individual, kemudian di era Marketing 4.0 menjadi keputusan secara bersama-sama baik melalui teman ataupun keluarga. Adanya hal tersebut yang melatarbelakangi seorang pakar pemasaran yaitu Philip Kotler, Hermawan Kartajaya, dan Iwan Setiawan mencetuskan customer path 5A terbaru yang digambarkan dengan orang mengenal, tertarik, bertanya, membeli, dan merekomendasikan (Kotler et al., 2017). Pemasar memiliki peran untuk dapat menjadi pembimbing kepada pelanggan sepanjang perjalanan mereka, yang dimulai dari kesadaran (Awareness) sampai tahap advokasi (Advocate). Pemasar atau pelaku usaha tentunya sangat mengharapkan terjadinya proses act dan advocate terhadap produk yang ditawarkan kepada konsumen saat era new normal ini. 
Penerapan dari customer path 5A dapat diketahui dari perilaku konsumen dalam melakukan suatu proses pembelian produk. Oleh karena itu, proses customer path 5A tidak dapat terlepas dari peran penggunaan media sosial, pengamatan terhadap perilaku konsumen saat melalui customer path $5 \mathrm{~A}$ akan digali dengan menggunakan media pemasaran online. Media sosial Instagram merupakan salah satu dari banyaknya media sosial yang sangat digemari dan banyak peminatnya dalam melakukan pemasaran secara online (Rahmawati, 2016). Pelaku usaha akan memanfaatkan fasilitas serta kelebihan dari aplikasi Instagram untuk menawarkan produk ataupun jasanya dengan cara memposting produk atau jasa yang ditawarkan tersebut serta tidak lupa juga menambahkan keterangan detail mengenai produk atau jasa yang biasanya disebut dengan istilah caption sehingga nantinya para calon konsumen akan dapat melihat jenis barang/jasa yang ditawarkan (Indah Kencana Putri, 2019).

Menurut data yang dirilis oleh Iman (2020), pada goodnewsfromindonesia.id, untuk periode Januari-Mei 2020, jumlah pengguna Instagram di Indonesia mencapai hingga 69,2 juta (69.270.000) pengguna. Pencapaian tersebut disebabkan oleh adanya peningkatan dari bulan ke bulan. Pengguna di bulan Januari mencapai sekitar 62,23 juta pengguna, lalu mengalami kenaikan di bulan Februari menjadi 62,47 juta pengguna. Pengguna pada bulan Maret dari platform Instagram semakin membeludak dan mencapai 64 juta pengguna. Pengguna mencapai 65,7 juta pada bulan April, hingga akhirnya ditutup pada bulan Mei dengan capaian 69,2 juta pengguna. Hal ini terjadi karena meroketnya penggunaan platform Instagram ditengah penerapan work from home (WFH) saat pandemi Covid-19. Pengguna Instagram di Indonesia lebih banyak berasal dari golongan usia produktif, yakni pada rentang usia 18-24 tahun, atau lazim disebut dengan generasi milenial atau dikenal juga dengan sebutan generasi Y.

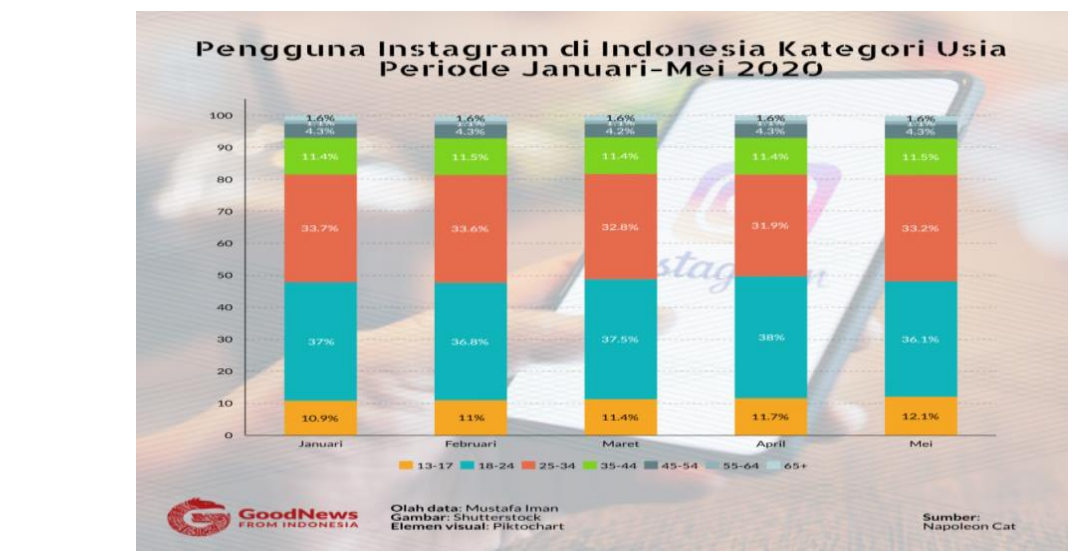

Sumber: goodnewsfromindonesia.id (2020)

Gambar 1.

Pengguna Instagram di Indonesia Kategori Usia

Generasi milenial memiliki tujuan yaitu adanya keseimbangan antara kehidupan dan pekerjaan, maka dari itu generasi ini akan lebih cenderung bekerja dengan fleksibel (Avianti \& Kartika, 2017). Menurut Putri (2018), mengemukakan bahwa generasi milenial juga mendapat sebutan sebagai anak-anak remote control, sebab generasi ini telah menghadapi suatu perubahan yang terjadi secara terus-menerus. Akan tetapi, generasi ini akan terus mencari suatu tantangan dengan perencanaan jangka panjang, memiliki sikap optimistis, juga dengan memiliki pemikiran yang kritis.

Pengguna Instagram di Indonesia periode Januari-Mei 2020 dari golongan generasi milenial mendominasi hingga 25 juta pengguna atau mendominasi $36-38$ persen (usia 18-24). 
Generasi milenial perempuan dengan rentang usia 18-24 yang menjadi subjek penelitian ini, karena media sosial Instagram merupakan salah satu platform yang saat ini sangat diminati dan menjadi popularitas. Pelaku usaha banyak yang melirik kepopuleran dari Instagram untuk menjadi alat penghubung antara penjual dan konsumen dalam memasarkan suatu produk atau jasa, dengan semakin banyaknya bisnis yang menggunakan Instagram, maka strategi merek tentunya akan diperluas agar dapat mencakup tujuan baru serta pemasaran bisnis akan berfokus kepada peningkatan terhadap kesadaran merek (Wahana, 2018). Instagram juga bersifat sebagai media yang efektif dan aktif dalam melakukan promosi, karena sangat praktis dalam penggunaannya serta tentunya bermanfaat terhadap penjualan produk, komunikasi antara penjual dan konsumen juga semakin mudah karena tersedianya fitur direct message yang sangat memudahkan penggunanya (Diningrum et al., 2021; Kurniawan, 2017; Puspitarini \& Nuraeni, 2019).

Penjual dan konsumen akan melakukan interaksi yang aktif dalam hal promosi produk, dengan menciptakan konten-konten yang menarik serta menambahkan fitur-fitur yang telah disediakan oleh Instagram maka dapat meningkatkan penjualan dan terjadinya perkembangan merek juga terciptanya engagement (Jesslyn \& Winduwati, 2021). Media sosial juga dapat menjadi media bisn is dengan memanfaatkan media sosial Instagram untuk dapat meraup keuntungan walaupun usaha yang dijalankan berada dalam kategori usaha rumahan kecil-kecilan dan proses promosi melalui Instagram tidak membutuhkan waktu yang lama, tidak memakan biaya sebab hanya mengunggah foto atau video (Handika et al., 2018; Ramadhan, 2017). Followers Instagram dapat dinaikkan dengan melakukan strategi marketing seperti memberikan potongan harga atau promo menarik, bisa juga mengadakan give away dengan memberikan gratis produk namun dengan ketentuan persyaratan harus follow terlebih dahulu (Dharmayanti \& Darma, 2020; Saefulloh \& Darma, 2014).

Pemanfaatan dari media sosial Instagram tentunya akan semakin dirasakan keberadaannya dalam melakukan promosi agar usaha yang dimiliki dapat tetap bertahan walaupun dimasa pandemi Covid-19 (Miladiyah \& Riyanto, 2020; Supriyani \& Untari, 2021). Peneliti tertarik untuk menggunakan akun Instagram Wimy Store sebagai objek penelitian. Wimy Store merupakan toko pakaian yang menjual berbagai macam outfit yang terupdate yang didesain dan diproduksi sendiri dengan menggabungkan interaksi tradisional dan juga digital dengan para konsumennya. Wimy S tore juga terkena dampak dari adanya pandemi Covid-19, namun masih tetap bisa bertahan sampai era new normal ini, karena memanfaatkan kepopuleran dari media sosial Instagram. Fenomena terjadinya perubahan perilaku konsumen saat proses pembelian membuat peneliti tertarik untuk meneliti pola pembelian oleh followers akun Instagram Wimy Store terhadap produk yang ditawarkan. Penelitian dilakukan dengan menggunakan konsep customer path 5A dengan pertimbangan adanya peran konektivitas dari setiap individu sehingga mempengaruhi tindakan pembelian produk dari suatu merek. Penelitian dengan konsep customer path 5A berfokus kepada customer yang dalam hal ini followers akun Instagram Wimy Store. Unsur-unsur yang terdapat pada customer path 5A yaitu Aware, Appeal, Ask, Act, dan Advocate adalah perilaku yang dilakukan oleh seorang individu, sehingga perilaku dalam melakukan proses pembelian oleh pengguna Instagram dapat dianalisis menggunakan customer path 5A.

Penelitian yang dilakukan oleh Irma (2017), dengan judul Peran Instagram Sebagai Media Komunikasi Pemasaran Bisnis Online menemukan bahwa Instagram memiliki peran sebagai media komunikasi pemasaran produk serta tidak adanya hambatan yang ditemukan oleh pemilik online shop maupun keempat adminnya selama memanfaatkan Instagram sebagai media komunikasi pemasaran, hal ini menunjukkan bahwa mudahnya dalam penggunaan media sosial Instagram. 
Penelitian lainnya yang dilakukan oleh Muna \& Miartana (2018), berjudul Pemanfaatan Media Sosial Dalam Memahami Perilaku Konsumen Terhadap Keputusan Pembelian mengatakan bahwa adanya faktor budaya, sosial, personal dan psikologis yang mempengaruhi perilaku konsumen sedangkan harga, kualitas, kenyamanan komunikasi dan faktor desain barang mempengaruhi keputusan pembelian.

Strategi komunikasi pemasaran dengan menggunakan Instagram dapat meningkatkan brand awareness, selain itu menggunakan media sosial Instagram juga dapat membangun customer engagement dengan para followers sehingga bisnis dapat terus berlanjut, dan dengan menggunakan strategi komunikasi pemasaran bagi para UMKM yang berfokus kepada platform digital tanpa meninggalkan pemasaran konvensional atau non digital sehingga para pelaku UMKM tentunya dapat bersaing di era new normal ini (Fariastuti \& Azis, 2019; Novianita et al., 2020; Rohadian, S. dan Amir, 2019). Akan tetapi, penelitian yang meneliti secara lebih dalam mengenai bagaimana persepsi dari perilaku milenial pengguna Instagram di era new normal terkait dengan penerapan New Customer Path 5A masih sangat terbatas. Penelitian ini bertujuan untuk mengetahui persepsi perilaku milenial pengguna Instagram di era new normal terkait dengan penerapan customer path 5A.

\section{METODE PENELITIAN}

Penelitian ini menggunakan pendekatan kualitatif yang bersifat deskriptif, untuk menjelaskan fenomena secara dalam dengan menggunakan data yang dikumpulkan, serta lebih menekankan pada kedalaman (kualitas) data bukan banyaknya (kuantitas) data (Sugiyono, 2018). Lokasi dari penelitian harus dilakukan dengan penentuan seperti mempertimbangkan teori substantive, melakukan pengamatan lapangan serta melakukan penyesuaian dengan kenyataan yang ada di lapangan (Moleong, 2018). Penelitian ini memilih Wimy Store sebagai objek penelitian, untuk pemilihan informan dilakukan dengan cara menggunakan metode purposive sampling, yaitu informan yang dipilih dianggap memenuhi suatu kriteria tertentu dari peneliti sehingga data yang diberikan oleh informan merupakan data yang tepat, akurat, mencukupi dan sesuai dengan tujuan penelitian. Penelitian ini menggunakan 10 orang informan milenial dengan kriteria: informan merupakan pengguna Instagram, informan merupakan follower dari akun Instagram Wimy Store, informan merupakan perempuan generasi milenial yang berusia 18 - 24 tahun, dan informan mengetahui tentang keberadaan Wimy Store.

Pengumpulan data dilakukan dengan melakukan observasi dengan cara mengamati aktivitas di Instagram Wimy Store dan juga melakukan observasi secara offline dengan langsung mengunjungi offline store dari Wimy Store. Peneliti melakukan wawancara dengan para informan, menggunakan teknik wawancara secara mendalam (in depth interview). Wawancara dilakukan secara langsung (bertatap muka) dengan menggunakan pedoman wawancara yang telah disusun sebagai panduan wawancara. Informasi yang diterima oleh peneliti dari informan direkam dengan menggunakan alat audio recorder agar dapat digali lebih dalam sepanjang penelitian dilakukan serta mendapatkan informasi yang berkaitan dengan data yang dibutuhkan. Dokumentasi dilakukan melalui literatur dan buku-buku yang memberikan informasi terkait dengan penelitian. Analisis data dilakukan dengan merekam proses wawancara menggunakan audio recorder, selanjutnya melakukan reduksi data melalui hasil rekaman dari audio recorder kemudian dituangkan dalam bentuk transkrip wawancara, kemudian membuat themeing dan coding, kemudian tahap selanjutnya melakukan penyajian data, dengan menguji keabsahan data menggunakan triangulasi sumber. Triangulasi sumber merupakan suatu teknik yang dilakukan dengan membandingkan atau mengecek ulang derajat kepercayaan suatu 
informasi yang diperoleh dari hasil yang berbeda (Sugiyono, 2013). Peneliti selanjutnya melakukan penarikan kesimpulan atas hasil temuan.

\section{HASIL DAN PEMBAHASAN}

Perilaku milenial pengguna Instagram pada tahap aware, sepuluh informan milenial merupakan followers dari akun Instagram Wimy Store mengetahui (Aware) terkait dengan keberadaan Wimy Store. Para informan untuk pertama kalinya mengetahui Wimy Store melalui media sosial Instagram dengan cara yang berbeda. Konsumen akan terpapar secara pasif pada daftar panjang merek baik dari komunikasi pemasaran, dan/atau anjuran orang lain, ataupun pengalaman masa lalu (pengalaman sendiri). Sumber pengenalan merek tersebut merupakan pintu gerbang menuju keseluruhan dari jalur pelanggan (Kotler et al., 2017). Konsumen melakukan cara agar dapat mengenali suatu merek dari aktivitas komunikasi pemasaran seperti iklan, dimana cara ini dipandang sebagai sumber awal serta memiliki pengaruh yang paling dangkal bagi konsumen. Iklan oleh perusahaan merupakan sumber kesadaran akan merek (Farela Devi, 2017). Satu diantara sepuluh informan mengetahui Wimy Store melalui komunikasi pemasaran dengan melihat postingan Instagram dari salah satu selebgram yang merupakan endorser dari Wimy Store. Sifat pemasaran dengan menggunakan jasa endorser tersebut sama dengan seperti iklan. Pemanfaatan dari jasa endorser akan menjangkau pangsa online secara lebih luas, dan memberikan pengaruh yang kuat saat melakukan endorse kepada para pengikutnya (Handika et al., 2018). Selebgram akan melakukan unggahan atau memposting foto atau video dari produk yang dipasarkan dengan memanfaatkan fasilitas serta kelebihan dari aplikasi Instagram untuk menawarkan produk tersebut serta tidak lupa juga menambahkan keterangan detail mengenai produk yang biasanya disebut dengan istilah caption (Indah Kencana Putri, 2019). Para followers dari selebgram dapat mengetahui produk yang digunakan dari mention(@) ataupun hashtag (\#) yang dicantumkan pada unggahannya tersebut.

Informan lainnya mengetahui (Aware) untuk pertama kali melalui rekomendasi komunikasi keluarga dan teman pada saat menggunakan produk dari Wimy Store kemudian membagikan postingan pada Instagram story. Rekomendasi dari keluarga dan juga teman dipandang lebih mengena atau lebih efektif apabila dibandingkan dengan komunikasi pemasaran, karena dianggap lebih dapat dipercaya sebab sebelumnya sudah adanya pengalaman nyata lebih dulu dari orang terdekat terhadap sebuah merek. Adanya kekuatan dari sebuah persepsi yang memberikan pengaruh terhadap rasa ingin tahu, dan juga minat dalam melakukan suatu pembelian produk, dimana hal ini juga merupakan salah satu tahap untuk mengevaluasi dan juga meyakinkan konsumen (Lugra Agusta Pranawa \& Abiyasa, 2019). Kesadaran atau awareness sangat penting untuk dibangun dalam suatu kegiatan pemasaran terhadap suatu produk yang ditawarkan. Wimy Store juga sadar akan hal tersebut, maka dari itu dalam melakukan pemasaran secara online Wimy Store memilih salah satu media sosial yaitu Instagram. Walaupun mengetahui (Aware) dengan sumber pengenalan merek yang berbeda, maka dapat disimpulkan bahwa para informan yang merupakan pengguna Instagram mengetahui Wimy Store untuk pertama kalinya melalui jaringan sosial Instagram. Penggunaan Instagram sebagai strategi komunikasi pemasaran dapat meningkatkan brand awareness dengan para followers sehingga bisnis dapat terus berlanjut (Fariastuti \& Azis, 2019; Novianita et al., 2020; Rohadian, S. dan Amir, 2019).

Perilaku milenial pengguna Instagram pada tahap appeal, ketertarikan mulai muncul karena adanya sentuhan pelayanan dari penyedia merek. Konsumen sebelumnya telah terpikir atau tersadar terhadap merek, selanjutnya konsumen akan melakukan seleksi, apabila merek tersebut menarik maka akan dipertimbangan secara lanjut, namun apabila merek tersebut tidak menarik maka akan dilupakan. 
Customer akan merasa tertarik saat merek tersebut memberikan sesuatu yang berbeda atau unik daripada merek yang lain (Halimawan, 2014). Sepuluh informan milenial yang sudah Aware terhadap keberadaan Wimy Store, kemudian merasa tertarik. Para informan memutuskan untuk mengikuti akun Instagram @ wimy_store sebagai wujud ketertarikan (Appeal) terhadap produk Wimy Store. Informan tertarik terhadap Wimy Store yaitu dilihat dari penyampaian informasi mengenai update produk yang kekinian/baru dengan mengikuti gaya milenial saat ini khususnya, selain itu dengan melihat dari cara pemasaran produknya, hal ini terlihat dari cara Wimy Store saat memposting produknya di Instagram. Informan tertarik untuk mengikuti akun Instagram Wimy Store juga dapat disebabkan oleh keadaan saat sedang mencari referensi produk yang diinginkan atau dibutuhkan.

Menurut Kotler (2017), untuk dapat membangun sebuah brand attraction dengan baik sehingga konsumen akan sampai kepada tahap appeal, maka terdapat enam aspek yang harus dimiliki, diantaranya melalui physicality (tampilan yang baik) dan juga intellectuality. Instagram Wimy Store (@wimy_store) memiliki tampilan yang menarik, yang dapat dibuktikan dari cara informan tertarik untuk mengikuti akun Instagram @ wimy_store sehingga mengetahui update-an terbaru dari produkproduknya. Pemasaran secara online atau digital saat era new normal ini juga semakin memiliki peran penting untuk dapat menyasar pasar secara luas, namun tidak dapat dipungkiri juga bahwa pemasaran secara offline tidak dapat ditinggalkan. Pemasaran yang dilakukan secara digital tidak sepenuhnya dapat menggantikan peran pemasaran secara tradisional, keduanya harus hidup saling berdampingan dengan peran yang saling bertukar di sepanjang jalur pelanggan. Pelanggan akan menuntut adanya suatu hubungan yang lebih erat dengan perusahaan saat interaksi berlanjut, sehingga dalam hal ini pemasaran digital menjadi sangat penting (Kotler et al., 2017).

Perilaku milenial pengguna Instagram pada tahap ask, konsumen sudah merasa antusias pada suatu merek, akan tetapi mereka ingin mendapatkan informasi lebih dalam lagi sebelum melakukan pembelian, dengan tujuan agar mereka semakin yakin akan merek tersebut (Halimawan, 2014). Pelanggan akan menindaklanjuti dengan cara meneliti secara aktif merek yang menarik bagi mereka untuk dapat memperoleh informasi lebih banyak baik dari teman dan keluarga, dari media sosial, ataupun dari mereknya langsung karena didorong oleh rasa keingintahuan. Para informan menyatakan bahwa informasi-informasi yang dibagikan oleh Wimy Store cukup lengkap terkait pilihan warna, dan juga bahan dari produk. Namun, Wimy Store tidak mencantumkan harga pada caption dari produknya, sehingga informan harus bertanya terkait dengan harga dari produk yang diminatinya. Beberapa para informan lebih memilih mencari informasi atau bertanya melalui fitur direct message yang tersedia pada Instagram. Informan menyatakan dengan adanya fitur direct message lebih praktis dan otomatis pada saat menggunakan Instagram, tentunya lebih memudahkan konsumen apabila ingin bertanya terkait produk yang ditawarkan. Namun, ada juga yang lebih memilih platform lain untuk memperoleh informasi yaitu dengan menggunakan aplikasi whatsapp daripada direct message di Instagram karena lebih seringnya penggunaan dari aplikasi whatsapp daripada direct message Instagram. Informan akan melalui tahap ini yang merupakan tahap terakhir sebelum memutuskan benar-benar melakukan pembelian. Keputusan untuk melakukan pembelian ataupun pada akhirnya tidak melakukan pembelian ditentukan dari jawaban yang didapat selama proses bertanya ini. Konsumen akan mencari informasi sampai benar-benar merasa yakin sebelum memutuskan untuk melakukan pembelian produk. Oleh sebab itu, bagi perusahaan penyedia merek penting untuk membuat konsumen merasa terlayani secara maksimal.

Perilaku milenial pengguna Instagram pada tahap act, apabila konsumen merasa yakin dengan informasi yang diterima dalam tahap bertanya, maka selanjutnya konsumen akan memutuskan untuk bertindak. Para informan dalam melakukan pembelian produk, tentunya memiliki suatu 
pertimbangan terlebih saat ini sedang berada di era new normal, yang mana konsumen akan sangat memperhatikan kebutuhannya yang sangat diperlukan, dan konsumen juga lebih melihat nilai dari suatu produk akibat adanya perubahan dari perilaku konsumen. Keputusan pembelian juga disebabkan oleh faktor harga termasuk melakukan perbandingan harga terhadap toko lainnya, melalui rekomendasi dan juga trend (Putra \& Darma, 2020). Dua dari sepuluh informan tidak melakukan tindakan pembelian (act) dengan pertimbangan adanya pandemi Covid-19. Informan lebih memilih untuk menekan keinginan dalam melakukan pembelian produk dan lebih mementingkan kebutuhannya yang diperlukan dengan melihat nilai dari produk. Berbeda hal dengan delapan informan lainnya yang melakukan pembelian produk di Wimy Store mengatakan bahwa mereka lebih senang untuk datang langsung ke toko offline dari Wimy Store walaupun saat ini sudah memasuki era new normal padahal pembelian secara online juga sudah tersedia. Informan lebih merasa nyaman apabila melakukan pembelian produk secara offline, hal lainnya karena dapat melihat serta mencoba produk yang diinginkan serta menjadikan peluang untuk melihat produk-produk lainnya secara langsung. Wimy Store juga sudah menerapkan kebijakan dari protokol kesehatan meskipun melakukan pembelian produk secara offline store di era new normal. Pemasaran secara offline atau tradisional akan memainkan peran utama dalam membangun sebuah kesadaran dan minat. Namun, kombinasi interaksi secara online dan offline akan selalu dibutuhkan untuk saling melengkapi (Kotler et al., 2017). Produktivitas usaha pemasaran dapat diukur oleh pemasar menggunakan Purchase Action Ratio (PAR), rumusnya yaitu act dibagi dengan aware sehingga apabila dihitung hasilnya sebesar 0,8 . Hasil ini diperoleh dari 10 orang informan yang mengenal Wimy Store, dan 8 orang informan yang pernah berbelanja di Wimy Store. Secara teori nilai PAR yang maksimal bernilai 1. Maka dalam penelitian ini, Purchase Action Ratio (PAR) dari Wimy Store dapat dikatakan baik karena bernilai lebih dari setengah apabila dibandingkan dari nilai maksimalnya.

Perilaku milenial pengguna Instagram pada tahap advocate, suatu merek atau produk tersebut dikatakan mendapatkan advokasi apabila dengan seiring berjalannya pengalaman dalam mengkonsumsi merek atau produk tersebut, customer tidak segan untuk merekomendasikannya kepada orang lain. Perusahaan menganggap terjadinya advokasi sebagai wujud sukses atau tidaknya produk tersebut diterima oleh konsumen (Mawarni \& Pamungkas, 2019). Dari delapan orang informan setelah melakukan pembelian produk, kemudian menjadi customer yang loyal dan melakukan advocacy produk Wimy Store kepada teman dan juga keluarganya. Para informan memiliki pengalaman yang baik dengan Wimy Store sehingga menjadi bukti bahwa informan telah loyal, sehingga ingin orang-orang terdekat juga merasakan pengalaman yang sama. Namun, berbeda hal bagi dua informan yang tidak melakukan rekomendasi atau advokasi. Menurut informan apabila belum melakukan pembelian produk tidak berani untuk melakukan rekomendasi, karena belum melihat dan mengetahui kualitas dari produk tersebut, sehingga informan tidak melakukan rekomendasi. Seseorang terkadang baru dapat melakukan suatu rekomendasi atau memberikan saran setelah memiliki pengalaman terhadap suatu produk atau telah menggunakan produk tersebut. Produktivitas usaha pemasaran dapat diukur oleh pemasar menggunakan Brand Advocacy Ratio (BAR), rumusnya yaitu advocate dibagi dengan aware sehingga apabila dihitung hasilnya sebesar 0,8 . Hasil ini diperoleh dari 10 orang informan yang mengenal Wimy Store, dan 8 orang informan yang pernah merekomendasikan Wimy Store kepada teman dan juga keluarganya. Secara teori, nilai BAR yang maksimal juga bernilai 1. Maka dalam penelitian ini, Brand Advocacy Ratio (BAR) dari Wimy Store dapat dikatakan baik karena bernilai lebih dari setengah apabila dibandingkan dari nilai maksimalnya.

Menelisik dari persepsi perilaku milenial pengguna Instagram followers akun Instagram Wimy Store terkait dengan penerapan customer path 5A, maka dalam penelitian ini tidak semua 
informan melalui setiap tahap dari customer path 5A yang dimulai dari tahap Aware, kemudian Appeal, dilanjutkan dengan Ask, kemudian konsumen akan Act sampai akhirnya konsumen berada di tahap Advocate. Akan tetapi, dalam penelitian ini dua informan hanya melalui tiga tahap dari customer path 5A, yaitu dimulai dari tahap Aware, kemudian Appeal, dan terakhir pada tahap Ask, dimana 2 tahap lagi yaitu Act dan Advocate tidak dilalui. Konsumen belum tentu akan melalui setiap fase pada customer path 5A, tidak harus berjalan urut, dapat melompat atau bolak-balik pada setiap unsur customer path 5A (Kotler et al., 2017).

\section{SIMPULAN DAN SARAN}

Konsep customer path 5A merupakan jalur atau tahapan perilaku pelanggan terhadap sebuah merek, dimana konsep ini memiliki tujuan akhir untuk menganjurkan merek tersebut kepada orang lain. Customer path 5A yang terdiri dari Aware, Appeal, Ask, Act, dan Advocate, telah menggantikan tahapan konsumen 4A yang terdiri dari Aware, Attitude, Act, dan Act Again, yang mana proses customer path $4 \mathrm{~A}$ ini sifatnya sangat individual. Konsumen belum tentu akan melalui setiap fase pada customer path 5A, tidak harus berjalan urut, dapat melompat atau bolak-balik pada setiap unsur customer path 5A. Berdasarkan penelitian yang telah dilakukan menemukan bahwa tahapan customer path 5A dari followers akun Instagram Wimy Store tidak melalui kelima tahapan dari customer path 5A yaitu mulai tahap Aware, kemudian Appeal, dilanjutkan dengan Ask, kemudian konsumen akan Act sampai akhirnya konsumen berada di tahap Advocate. Akan tetapi, informan hanya melalui tiga tahap dari customer path 5A, yaitu dimulai dari tahap Aware, kemudian Appeal, dan terakhir pada tahap Ask, dimana 2 tahap lagi yaitu Act dan Advocate tidak dilalui. Act atau tindakan pembelian tidak dilakukan karena adanya pertimbangan pandemi Covid-19 sehingga lebih memilih untuk menekan keinginan dalam melakukan pembelian produk dan lebih mementingkan kebutuhannya yang diperlukan dengan melihat nilai dari produk, Advocate tidak dilakukan karena belum pernah terjadi Act sebelumnya. Penelitian ini memiliki implikasi bagi para pelaku usaha atau pemilik bisnis dan juga departemen pemasaran dalam hal menjalankan bisnis atau usaha dengan memanfaatkan media sosial khususnya

\section{REFERENSI}

Barokah, S., Andina, A. N., \& Anggiany, Z. (2020). STRATEGI ADAPTIF KEDAI KOPI “ COFFEE BREAK ” PURWOKERTO.01(12), 150-160.

Dharmayanti, P. D., \& Darma, G. S. (2020). The use of instagram in coffee shop. International Research Journal of Management, IT and Social Sciences, 7(4), 48-56.

Diningrum, D. F., Nura ini, E., Anisa, K., \& Sa putra, D. I. S. (2021). Pemanfaatan Media Sosial Sebagai Sa ra na Pomosi Pada Bisnis Ja mur Crispi Fen Claire. JurnalManajemen Dan Bisnis, 2(1), 6-12.

Farela Devi, D. G. S. (2017). Celebrity Endorser, Daya Tarik Iklan, Brand Awarene ss Dan Brand Attitude. ManagementDan Bisnis, 11(1),35-47.

Faria stuti, I. (Univ. P. D. M. (Beragama)), \& Azis, M. A. (2019). STRATEGI KOMUNIKASI PEMASARAN OneFourThree.Co Di Instagram Da lam Meningkatkan Brand Awareness. Jurnal Pustaka Komunikasi, 2(1),54-69. https://journal.moestopo.ac.id/index.php/pustakom/article/view/871

Handika, M. R., Maradona, A. F., \& Dharma, G. S. (2018). Strategi Pemasaran Bisnis Ku liner Menggunakan Influencer Melalui Media Sosial Instagram. Jurnal Manajemen Dan Bisnis Undiknas, 15(2), 192-203. https://doi.org/10.38043/jmb.v15i2.601

Iman, M. (2020). Pengguna Instagram di Indonesia Kategori Usia. https://www.goodnewsfromindonesia.id/2020/06/14/pengguna-instagram-di-in d one sia-did ominasiwanita-dan-generasi-milenial

Indah Kencana Putri, L. P. (2019). Perilaku Konsumen Pengguna Instagram di Era Marketing 4.0. Jurnal Manajemen Bisnis, 16(4), 20-31.https://doi.org/10.38043/jmb.v16i4.2248 
Irma, A. (2017). Peran Instagram Sebagai Media Komunika si Pemasaran Bisnis Online (Studi Deskriptif Kualitatif PadaBisnis Online Beautyhomeshop). Jurnal Online Kinestik, 4(2), 1-12.

Jesslyn, J., \& Winduwati, S. (2021).Pemanfaatan Media Sosial Instagram Pada Online Shop @ivoree.id dalam Memasarkan Produk. Prologia, 5(1), 135-141.https://doi.org/10.24912/pr.v5i1.8178

Kanten, I.K; Darma, G. S. (2017). Consumer Behaviour, Marketing Strategy, Customer Satisfaction, a nd Business Performance. Jurnal Manajemen Dan Bisnis, 14(2), 143-165.

Kotler, P. and Keller, K. (2021). Marketing Management MARKETING MANAGEMENT Marketing Management. Marketing Management.

Kotler, P., Harmawan, K. and, \& Iwan, S. (2017). Marketing 4.0 Moving from Tradicional to Digita l. In LID Editorial.https://doi.org/10.1017/CBO9781107415324.004

Kurnia wan, P. (2017). Pemanfaatan Media Sosial Instagram Sebagai Komunikasi Pemasaran Modern Pada Batik Burneh. Manajemen Fakultas Ekonomi Dan Bisnis Universitas Trunojoyo Madura, 1 1(2), 217-225. http://journal.trunojoyo.ac.id/kompetensi/article/view/3533

Lugra Agusta Pranawa, I. P., \& Abiya sa, A.P. (2019). Digital Marketing dan Hedonisme Dalam Pen gambilan Keputusan Pembelian. Jurnal Manajemen Bisnis, 16(4), 58-74. https://doi.org/10.38043/jmb.v16i4.2250

Mawarni, D. M., \& Pamungkas, I. N. A. (2019). Analisis Customer Path 5A Pada Instagram Tcash. EProceeding of Management, 6(1), 1403-1411.

Mila diyah, A. F., \& Riyan to, S. (2020). Pemanfaatan Media Sosial Instagram Dalam Pemasaran Say uran Oleh Sayurkita.Mlg Saat Masa Pandemi Covid 19. Jurnal Indonesia Sosial Sains, 1(3), 172-179. http://jiss.publikasiindonesia.id/

Moleong, L. J. (2018). Metodologi Penelitian Kualitatif, cet. In XI. Bandung: PT Remaja Rosdakarya.

Muna, N., \& Miartana, I.P. (2018). Pemanfaatan Media Sosial Da lam Memahami Perila ku Konsumen Terhadap Keputusan Pembelian. Jurnal Manajemen Dan Bisnis, 15(1), 19-45.

Novianita, R., Rahmawati, N. F., \& Nurba iti, D. (2020). Strategi Komunikasi Pemasaran Usaha Mikro Kecil dan Menengah Pada Era New Normal. Jurnal Ilmu Sosial Dan Manajemen, 7(2), 21-28.

Pratama, I. M. A., \& Darma, G. S. (2014). Stra tegi Penerapan E-CommerceDa lam Meningkatkan Keu nggu lan Bersaing. Jurnak Manajemen Dan Bisnis, 11(1), 69-81. http://journal.undiknas.ac.id/index.php/magister-manajemen/

Puspitarini, D. S., \& Nura eni, R. (2019). Pemanfaatan Media Sosial Sebagai Media Promosi (Stu di De sk rip tif pada Happy Go Lucky House). Jurnal Common, 3(1), 71-80.

Putra, I. K. R., \& Darma, G. S. (2020). Process of decisions making purchase online on Instagram social m edia . Journal of Business, Economics \& Management, 3(1), 165-171. https://sloap.org/journal/index.php/ijbem/article/view/167

Ramadhan,F.H. (2017).Pemanfaatan Media Sosial Instagram Akun @ Mr.CreamPuff Sebagai Promosi Da lam Meningkatkan Penjualan. Jom Fisip, 4(2), 10-25.

Rohadian, S. dan Amir, M. T. (2019). Upaya Membangun Customer Engagement Melalui Media Sosial Instagram ( Studi ka sus : online shopyang menjual produknya sendiri). Journal of Entreprene urship, Management, and Industry (JEMI), 2(4), 179-186.

Saefulloh, D. A., \& Darma, G. S. (2014). Strategi Marketing Wisata Wedding Sebagai Destinasi Alterna tif. Jurnal Manajemen Dan Bisnis-Undiknas Graduate School, 11(1), 17-34. http://journal.undiknas.ac.id/index.php/magister-manajemen/

Sudiyar Dalimunthe, A. (2020). Penerapan Manajemen Risiko Bagi Industri Pera suransian AgarTetap Survive Dan Kompetitif DiEra New Normal. Ejournal.Stma-Trisakti.Ac.Id, 7(1), 46-54.

Sugiyono. (2018). Metode Penelitian Kuantitatif,Kualitatif dan R\&D. In Ke-26.

Supriyani, N., \& Untari, D. (2021). Strategi dan Pemanfaatan Media Sosial Usaha Kecil dan Menengah (UMKM) Bertahan di Tengah Pa ndemi Covid-19. Jurnal Ekono Insentif, 15(1), 1-9. 